\title{
Analysis of the Effects of Three Various Current Control Methods on BLDC Motors
}

\author{
Mehmet Cihat ÖZGENEL*iD \\ Erzincan Binali Yıldırım University, Engineering Faculty, Depeartment of Electric Electronics Engineering, \\ Erzincan, Turkey.
}

Geliş / Received: 26/08/2019, Kabul / Accepted: 15/12/2019

\begin{abstract}
Brushless direct current motors are very popular motors in a wide application area thanks to their superior features. Brushless motors are the most preferred motors in applications such as domestic, robotics, office machines, medical, military and space applications, unmanned aerial vehicles applications because they meet the special requirements of these applications. Brushless direct current (BLDC) motors have high volume torque ratio, high efficiency, fast dynamic response; they offer linear torque/speed characteristics. Speed control of BLDC motors achieves by implementing pulse width modulation (PWM) technique. Various PWM control methods are put in to use for controlling of BLDC motor speed. These PWM methods have some certain advantages and disadvantages. In this study, three current control PWM methods which are mostly used in practices are examined. These are full conduction mode, independent and complementary PWM methods. For this purpose, three BLDC motor pre-drivers have been designed and manufactured and the effects of these three drivers on the BLDC motor have been examined. It has been found that complementary PWM mode has given to BLDC motor fast dynamic response. Full conduction mode has drawn higher de link current from DC power supply. Independent PWM method performance is very close to complementary PWM method.
\end{abstract}

Keywords: BLDC Motor, Current Control, Pulse Width Modulation, Speed Control of BLDC Motors.

\section{Üç Farklı Akım Kontrol Yönteminin BLDC Motorlardaki Etkilerinin İncelenmesi}

\section{Öz}

BLDC motorlar üstün özelliklerinden dolayı geniş bir uygulama alanında çok popüler motorlar olmuşlardır. Fırçasız motorlar ev, robotik, ofis makineleri, tıbbi, askeri ve uzay uygulamalarında, insansız hava araçlarında bu uygulamalardaki ihtiyaçları karşıladıkları için tercih edilirler. BLDC motorlar yüksek verim, hızlı dinamik cevap, lineer hız-moment karakteristiği ve yüksek hacim moment oranına sahiptirler. BLDC motorlarda hız ayarı PWM tekniği ile yapılır. Farklı PWM metotları BLDC motorlar için uygulanmaktadır. Bu PWM metotların üstünlükleri ve mahsurlu yanları bulunmaktadır. Bu çalışmada çok kullanılan üç değişik PWM metodu incelenmiştir. Bu metotlar; tam iletim modu, bağımsız PWM modu ve tamamlayıcı PWM modu metotlarıdır. Bu amaç için üç inverter ön sürücüsü tasarlanmış ve gerçekleştirilmiş ve metotların BLDC motor üzerindeki etkileri incelenmiştir. Tamamlayıcı PWM modlu inverterin FDAM'una hızlı bir dinamik tepki kazandırdığg görülmüştür. Tam iletim modu ile çalışan inverterin doğru akım kaynağından daha yüksek akım çekmektedir. Bağımsız PWM modlu inverterin performansının tamamlayıcı modlu inverterin performansına yakın olduğu görülmüştür.

Anahtar Kelimeler: BLDC Motor, Akım Kontrol, Darbe Genişliği Modülasyonu, BLDC Motorların Hız kontrolü.

\section{Introduction}

Brushless direct current motors have some special advantages over the brushed direct current and induction motors (Pindoriya, R. M. et al., 2014; Batham R. and Singh R.
2017). BLDC motors have a good linear relationship between torque and speed; they don't need maintenance owing to absence of brushes and commutator, high power 
density and efficiency, fast dynamic response, easy speed control. Thanks to these superior features, BLDC motors have been a good choice in a wide range of applications (Pindoriya, R. M. et al., 2014; Ozgenel M. C., 2017). Although BLDC motors have these superior features, they have also some disadvantages such as they need a driver for running even at fixed speed and initial cost is relative expensive compared to brushed and induction motor for the same power (Sathyan A. et al., 2009; Pindoriya, R. M. et al., 2014; Lengade S.R. and Mahjan D, 2018). In fact, these disadvantages are not indispensable importance, because induction and brushed motors also need drivers in a certain application that requires speed control. Now days, speed control is applied almost every applications due to fact that speed control ensures energy saving, reduces number of mechanical components in the system and prevents electrical and mechanical strain of the system. BLDC motor speed control is achieved by varying phase voltage employing pulse width modulation technique (Patel Vinod KR Singh and Pandey A. K., 2013; Arjun V. N., et al. 2016). Using PWM method ensures energy saving and efficiency compared to analog method in power electronics applications (Pindoriya, R. M. et al., 2014). PWM is the most used current control method in power control applications in power electronics (Mahesh S., et al., 2017).

In pulse width modulation method, conduction and non-conduction times (duty cycle) of power switches in inverter are changed in a fixed period. Thus, the speed and torque of the motor are changed by varying the terminal voltage of BLDC motor phase windings.

\section{Running of BLDC Motor}

A BLDC motor is a form of brushed direct current motor that is replaced its commutator and brushes with electronic commutation mechanism. While commutation is done via mechanical commutator and brushes in brushed $\mathrm{dc}$ motors, it is accomplished electronically in BLDC motors (Ozgenel M. C., 2017). In order to accomplish commutation in BLDC motors rotor position information is required. Rotor position information is achieved by using three Hall-effect magnetic sensors placed 120-degree apart on the stator of BLDC motor. Three Halleffect sensors produce rotor position information as logic 1 and logic 0 roughly. There are six position states in one electrical period. Commutation circuit produces gate signals of power transistors in inverter according to rotor position information in order to energize the two phase windings just aligned with the rotor magnets. Thus, the magnetic field of the rotor magnet and the magnetic fields creating by phase current in the phase windings push each other and the rotor starts to rotate and it builds up speed and torque. The rotor position information changes after the rotor 60-electrical degree moves, and the commutation circuit generates new gate signals of transistors to energize the phase winding exactly aligned with the pole of rotor magnet. In this way, the rotor continues to rotate according to a renewed rotor position at every 60 -electrical degree by energizing suitable two phase windings. Table 1 shows the sequence of energizing phase windings with respect to rotor position information. A typical three-phase inverter for BLDC motor driving is shown in Figure 1. There are six power transistors in inverter which can be insulated gate 
bipolar transistor (IGBT) or metal oxide semiconductor field effect transistor (MOSFET). MOSFET is a low-current and voltage but high-frequency switching device. MOSFET is a voltage controlled switch. Because there is body-drain diode in MOSFETs, it is useful in dealing with freewheeling current applications. Since the resistance between drain and source is low, conduction losses are also lower. MOSFETs can operate at high frequencies and low voltages and they are perfectly suitable for faster switching operations with low-voltage drops. But these are restricted to be used at higher operating voltages in the range of around $500 \mathrm{~V}$. MOSFETs can operate in parallel each others.

Table 1. Sequence of energizing phase windings according to rotor position in BLDC motor.

\begin{tabular}{|c|c|c|c|c|c|c|c|c|c|c|c|c|}
\hline \multirow{3}{*}{ Step } & \multicolumn{3}{|c|}{$\begin{array}{l}\text { Rotor } \\
\text { position } \\
\text { sensors }\end{array}$} & \multicolumn{6}{|c|}{$\begin{array}{l}\text { Status inverter transistors } \\
\text { according to rotor position } \\
\text { sensors }\end{array}$} & \multicolumn{3}{|c|}{$\begin{array}{c}\text { Phase } \\
\text { polarity }\end{array}$} \\
\hline & \multirow[t]{2}{*}{$\mathbf{S}_{\mathbf{C}}$} & \multirow[t]{2}{*}{$\mathbf{S}_{\mathbf{B}}$} & \multirow[t]{2}{*}{$\mathbf{S}_{\mathrm{A}}$} & \multicolumn{2}{|c|}{$\begin{array}{c}\text { Phase } \\
\text { A }\end{array}$} & \multicolumn{2}{|c|}{$\begin{array}{c}\text { Phase } \\
\text { B }\end{array}$} & \multicolumn{2}{|c|}{$\begin{array}{c}\text { Phase } \\
\text { C }\end{array}$} & \multirow[t]{2}{*}{$\mathbf{A}$} & \multirow[t]{2}{*}{ B } & \multirow[t]{2}{*}{ C } \\
\hline & & & & A- & $\mathrm{A}+$ & B- & $\mathrm{B}+$ & C- & $\mathrm{C}+$ & & & \\
\hline 1 & 0 & 0 & 1 & off & off & on & off & off & on & 0 & - & + \\
\hline 2 & 1 & 0 & 1 & off & on & on & off & off & off & + & - & 0 \\
\hline 3 & 1 & 0 & 0 & off & on & off & off & on & off & + & 0 & - \\
\hline 4 & 1 & 1 & 0 & off & off & off & on & on & off & 0 & + & - \\
\hline 5 & 0 & 1 & 0 & on & off & off & on & off & off & - & + & 0 \\
\hline 6 & 0 & 1 & 1 & on & off & off & off & off & on & - & 0 & + \\
\hline 1 & 0 & 0 & 1 & off & off & on & off & off & on & 0 & - & + \\
\hline
\end{tabular}

IGBTs are suitable for medium to highpower applications. It is a minority charge carrier device and has high input impedance. IGBT usage is predominated for higher voltage applications as it is unipolar and requires additional freewheeling diode for the reverse flow of current. Because of this additional diode across the IGBT it ensures very high performance compared to the MOSFET without body diodes. While the operating voltage of the IGBTs is up to 1400 volts, but the operating voltage of the MOSFETs is up to 600 volts. Higher operating voltages of IGBTs ensure that the current is low and therefore the switching losses are lower (www.efxkits.us, 2019). MOSFETs are needed less gate drive elements and they are easily driven than IGBTs. IGBTs also need dedicated gate drive chips, but MOSFETs can easily be driven than IGBTs.

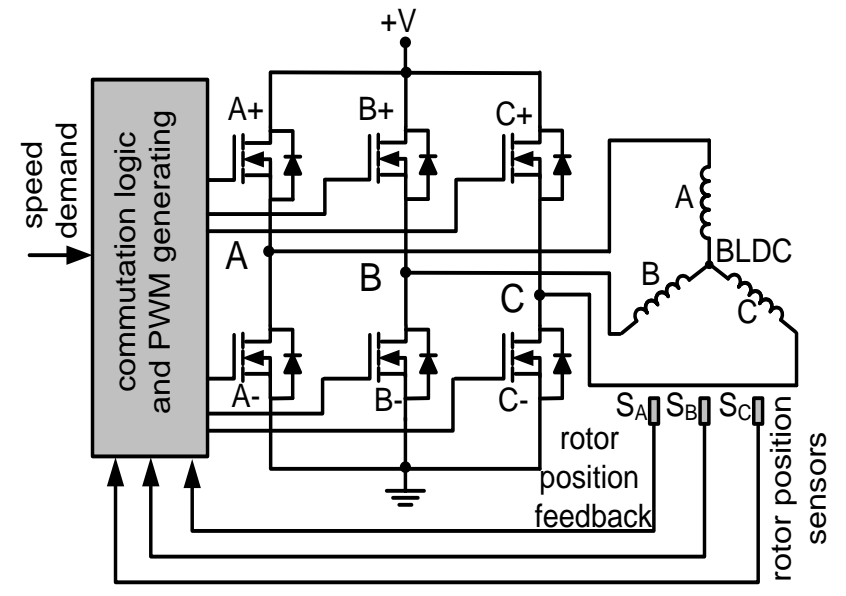

Figure 1. BLDC motor driving scheme.

\section{Speed Control of BLDC Motor Employing PWM Method}

Speed control of BLDC motor is done by varying the voltage of phase windings terminals as it is in brushed direct current (DC) motors. The voltage across the phase winding can be varied implementing 
analogue or digital switching method to power-transistors in inverter. Owing to have some restricts and the higher switching loss of analogue method, digital switching method is preferred in all electric power control applications (Pindoriya, R. M. et al., 2014). This digital switching method is known as pulse width modulation technique (PWM). In PWM current control technique, without making any changing in DC voltage source, DC voltage source is applied to the load in a very short time at several times during a period. By varying of the application time of DC voltage source to load is changed the load average voltage. The application of the DC source voltage to the load with short intervals is carried out by running the power transistor on and off states. Thus, PWM consists of on and off states of the power transistor in a period. If on time of power transistor is longer than it's off time, the load average voltage is increased. On the contrary, if on time of power transistor is less than its off time of power transistor, the load average voltage is decreased. Therefore, the load average voltage can be easily changed by varying the on and off states of the power transistor. The rate of the $t_{\text {on }}$ time of the switch to the period $\left(t_{o n}+t_{\text {off }}\right)$ is called duty cycle ratio. The relationship between average voltage, input voltage and duty cycle is expressed as following;

$V_{a v g}=\frac{t_{o n}}{t_{o n}+t_{o f f}} \cdot V_{D C}$

Considering the duty cycle, equation (1) is rewritable;

$V_{a v g}=\mathrm{D} \cdot V_{D C}$

Where $V_{\text {avg }}$ is the output voltage, $t_{\text {on }}$ is the conduction time of power transistor, $t_{\text {off }}$ is the non-conduction time of power transistor, $\mathrm{D}$ is the duty cycle ratio and $V_{D C}$ is source voltage.

In BLDC motor drivers, if duty cycle is $\% 100$, the average phase voltage is expressed as follows (Ozgenel M. C., 2017);

$V_{\text {phase }}=0.41 . V_{D C}$

Taking into account equations (2) and (3), if PWM is applied to BLDC motor windings, the value of the voltage in the phase windings can be written as follows;

$V_{\text {phase }}=0.41 \cdot D \cdot V_{D C}$

Therefore, by varying the duty cycle (D) value in equations $(1,2,4)$ the motor phase voltage is changed. Owing to fact that the speed of BLDC motors is directly proportional to phase voltage, the speed of BLDC motor can easily be controlled by varying duty cycle value in open loop or closed loop applications (Patel Vinod KR Singh and Pandey A. K., 2013; Tade S.L., et al., 2016; Arjun V. N., et al. 2016). In other words, the speed and torque of the BLDC motor are changed implementing the PWM method.

Owing to fact that BLDC motors are the most preferred motors in every area numerous commercial manufacturers produce PWM control chips targeted BLDC motor control (Ohm Dal Y. and Oleksuk R. J., 2002) such as MC33033 from Motorola, On semiconductor Corporations, FCM 8201 from Fairchild Corporation, L6235 from ST Microelectronics, DRV8332 from Texas Instruments, MC34929 from Freescale Semiconductor, Inc. and etc. While FCM 8201 and MC33033 are predriver ICs for inverter power transistors but L6235, DRV8332 and MC3429EP are 
directly for driving BLDC motor. But some of chips targeted to BLDC motor control have some restricts and bad efficiency and also undesirable sound for some special applications. However there are different PWM schemes which give satisfactory performance to BLDC motor driving system (Ohm Dal Y. and Oleksuk R. J., 2002). In this experimental study, 3 different PWM methods which are used switching BLDC motor driving system will be examined and the results will be discussed in detail in the section 7 .

\section{PWM Switching Schemes}

BLDC motors are mostly controlled by sixstep switching mode. In this mode, suitable power transistors in inverter shown in Figure 1 are switched according to three-bit rotor position information. In BLDC motors, in order to produce maximum torque in any rotor position, the phase current must pass through the two-phase windings which are aligning with the rotor poles to be pushed by the winding magnetic field continuously. In BLDC motor inverters, any two-phase winding is energized at 120-electrical degree. Because commutation occurs at every 60-electrical degree one phase winding is connected to positive terminal of power supply and other phase winding is connected to negative terminal of power supply and these phase windings are connected series each other. Thus, the windings which are connected in series to each other vary in at each 60electrical degree, but phase current passes through each phase winding during 120electrical degree. It is necessary to change the phase current passing through the phase windings in order to control speed and torque. This can be easily implemented employing PWM method. There are various PWM schemes to control phase current in
BLDC motor drivers. Each scheme has its own superior and disadvantageous properties. In this experimental study, three PWM methods are used in BLDC motors have been designed, manufactured and tested. These are;

\subsection{Full conduction mode (Variable DC Link Voltage, FCM)}

Although the using of this method is few, it is still used in some applications where high dynamic performance is not required. Because it is necessary to change the phase voltage to control BLDC motor speed, variable bus voltage control is employed in this topology as seen in Fig. 2 (Ohm Dal Y. and Park J. H., 1999). In this switching scheme, since power transistors in inverter run full conduction mode (FCM) during 120-electrical degree, this method is called six-step drive. For variable voltage, DC bus voltage is changed by thyristor bridge as shown in Fig. 2. In this topology, the energizing of the phase windings is made according to the three-bit rotor position information in the sequence shown in Table 1. In Table 1, at step 2, A-phase winding is connected to positive terminal of DC source $\mathrm{B}$-phase winding is connected to negative terminal of DC source and C-phase winding is float, in this step A and B-phase windings are connected in series by $\mathrm{A}+$ and $\mathrm{B}$ transistors. By the third step, while A-phase winding is still connected to positive terminal of DC source, but B-phase winding is float and $\mathrm{C}$-phase winding is now connected to negative terminal of DC source by A+ and C- transistors. In this step, A-phase winding is connected in series with C-phase winding. Then, in the fourth step, A-phase winding becomes float state Cphase winding which remains its negative polarity is connected in series with B-phase 
winding connected to positive terminal of DC source by $\mathrm{C}$ - and $\mathrm{B}+$ transistors. Thus, from step 2 to step 4 A-phase winding has run with B-phase during 60-electrical degree later it has run with C-phase during 60-electrical degree. Thus, while each phase winding works together each other 60-electrical degree, but each phase runs 120-electrical degree. In every step, only two phases of three phase's windings are energized. One phase is always positive and another phase is always negative during 120-electrical degree in this inverter topology. Energizing phase windings are made this manner according to Table 1 . Since DC bus voltage is a function of triggering angle of thyristor bridge in order to control BLDC motor speed the firing angle of thyristors is changed in this driving topology (Ohm Dal Y. and Park J. H., 1999). In this mode, the voltage applied motor phase windings is 120 degrees and has a rectangular wave shape as it is shown in Fig 6(a). This configuration has some main drawbacks such as it has rich harmonics resulting losses in motor and needs a bulky capacitor in the DC bus line but this switching scheme has low switching losses (Gamazo-Real J.C., et al., 2010). Of course, the only way is not to obtain the DC voltage from the thyristor bridge, but there are also other forms of voltage sources such as DC-DC converters and AC-DC variable voltage sources.

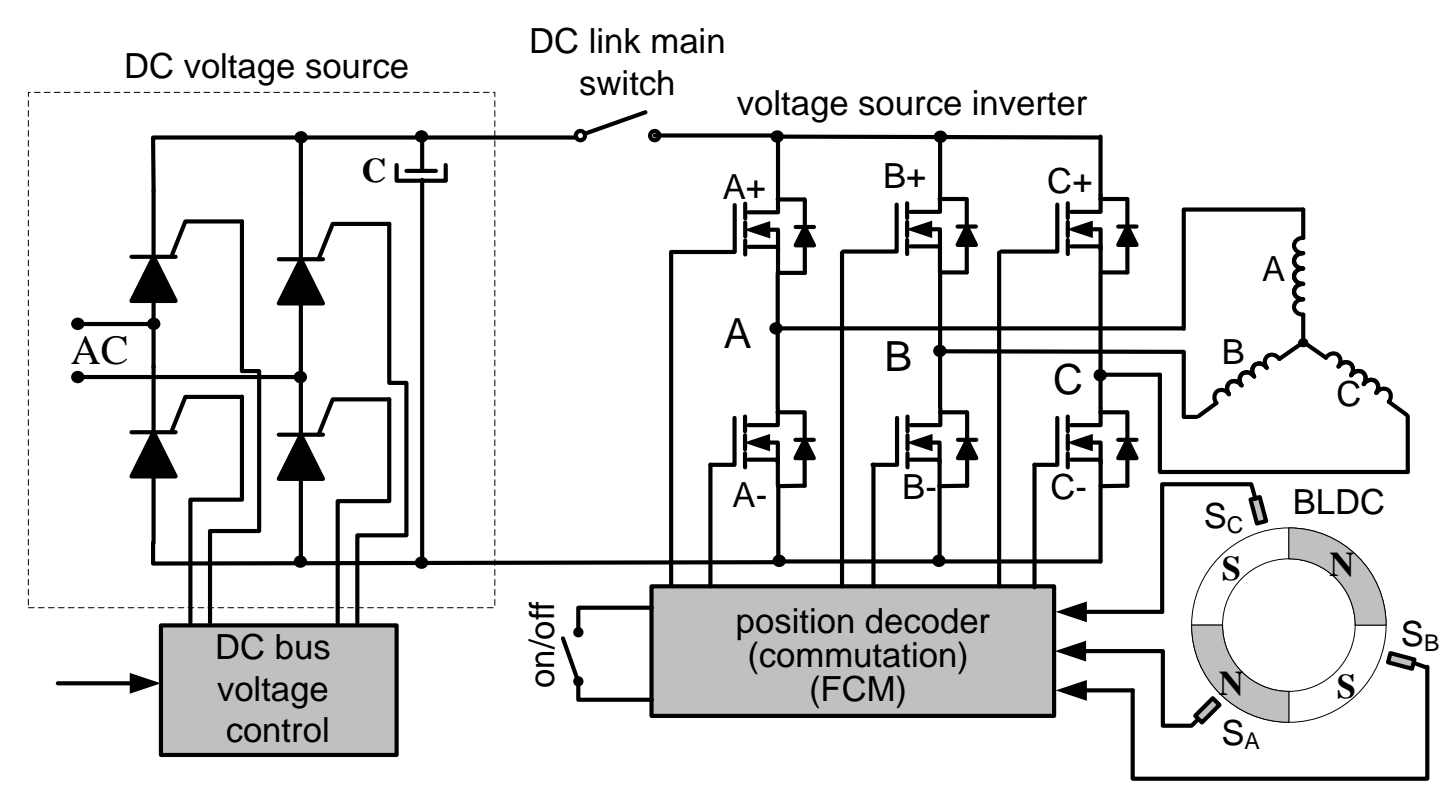

Figure 2. Variable DC Bus voltage BLDC motor driver.

\subsection{Independent PWM mode (IPWM)}

Inverter output voltage can be controlled by implementing PWM (IPWM) switching method to upper $(\mathrm{A}+, \mathrm{B}+, \mathrm{C}+)$ or lower sides switches (A-, B-, C-) in inverter.
However, considering the ease of driving transistors, it is preferred to drive the transistors in the lower sides of the inverter. Upper side transistors in the inverter are on full conduction mode (120-degree). Thus, while upper sides transistors are on conduction mode at 120-degree in a period, 
but lower side of transistors of inverter are run in PWM mode at 120-degree. So, variable voltage from output of inverter is obtained and BLDC motor speed and torque are controlled. Fig. 3 illustrates the structure of independent PWM mode.
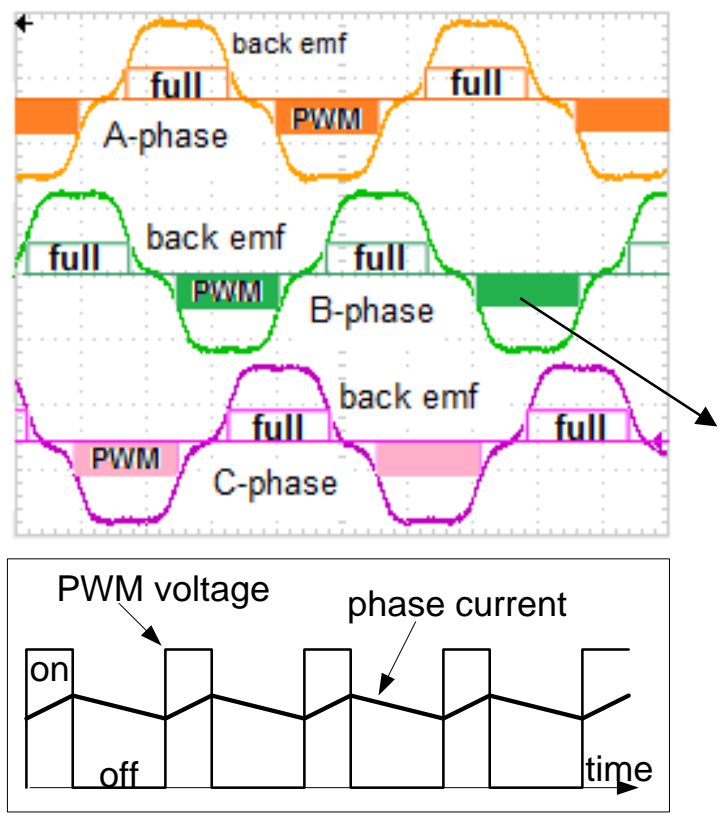

Figure 3. Structure of independent PWM switching mode.

In Fig. 3, while A-phase upper side transistor is at full conduction mode, lower side transistor run PWM mode. The other phase transistors run the same way. In this PWM scheme, when a PWM transistor is off, the phase current decreases slowly depending on the time constant of the phase winding (L/R). Because, this configuration is not suitable fast torque reversal on BLDC motors, it is exclusively imposed torque and speed directions are the same directions in other word 2-quadrant operation of BLDC motor is possible in this scheme (Ohm Dal Y. and Park J. H., 1999). Although independent PWM (IPWM) mode method has low switching losses in the inverter, but it has rich harmonics which results increase of losses in the BLDC motor. Since only transistors connected to the negative side of the DC source operate in PWM mode, it is easier to detect the rotor position using back electromotive force in sensorless applications (Gamazo-Real J.C., et al., 2010). Since control of power electronics circuitry is easy and simple design, this configuration is relatively low cost.

\subsection{Complementary PWM mode (CPWM)}

In this PWM structure, PWM is applied to both the top and bottom transistors of the same phase with a small dead time to avoid short circuit of DC source. So, decreasing of phase current becomes quicker during PWM off time. In Fig. 4, while A+ transistor is on, A- transistor is off state. When $\mathrm{A}+$ transistor is switched off state Atransistor is also off state this time. After $\mathrm{A}+$ switch is turned off, A- switch is turned on state after a short time that is called dead time, so both switches are not turned on at the same time and short circuit of DC source is prevented. Turning A- switch is on that ensures the phase current falls down quickly. This operation is the same for the $\mathrm{B}+, \mathrm{B}$ - and $\mathrm{C}+$ and $\mathrm{C}$ - switches. This mode of operation ensures a finer phase current control and removes the ripples on the current and torque as it is seen in Fig. 4. In addition, the 4-Quadrant operation is possible in this switching method. The complementary PWM (CPWM) scheme is preferred when fast speed reversal is required as in servo applications. The main drawbacks of this PWM method have higher switching losses and its design is more complex than the two other switching modes. 


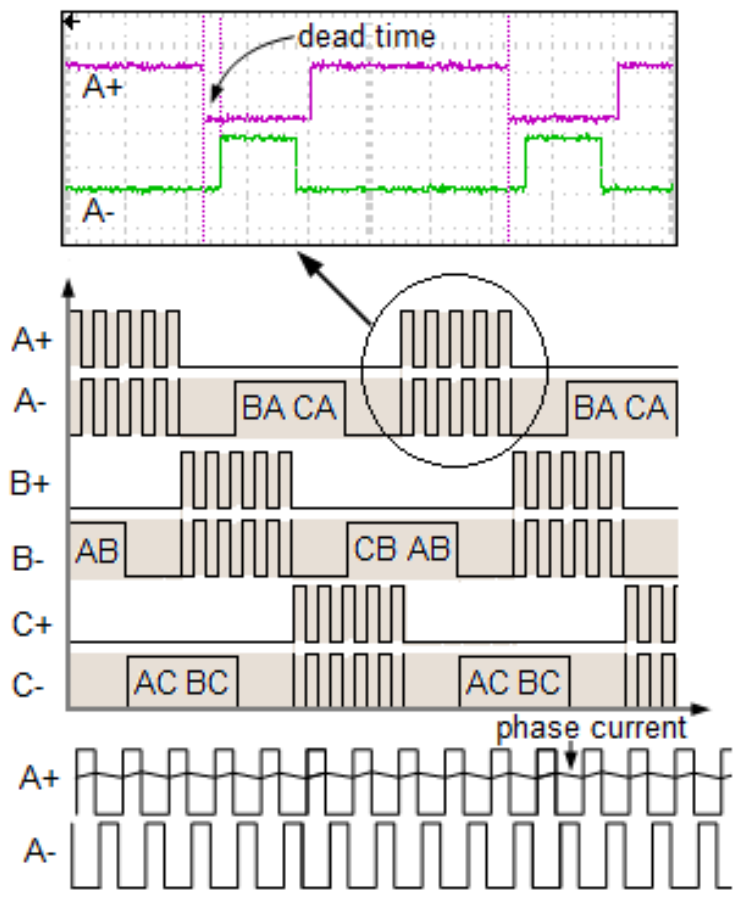

Figure 4. Complementary PWM switching method.

\section{Experimental Setup}

Three BLDC motor drivers using different PWM switching methods that are already mentioned in previous section have been designed and implemented to analyze the results. The first driver is variable DC bus voltage driver that can commutate inverter transistors according to rotor position. Inverter output voltage is changed by DC bus voltage in order to control speed of BLDC motor. The second one is independent PWM controlled inverter which is based SG3526 PWM generator chip using as inverter pre driver and PWM frequency is selected $20 \mathrm{kHz}$. In this driver the bottom transistors of inverter is run PWM mode but upper transistors of inverter run full conduction mode during 120electrical degree. The third one is complementary PWM driver based on FCM8201 BLDC motor pre-driver. In this PWM mode, one phase upper and lower transistors are run PWM mode.

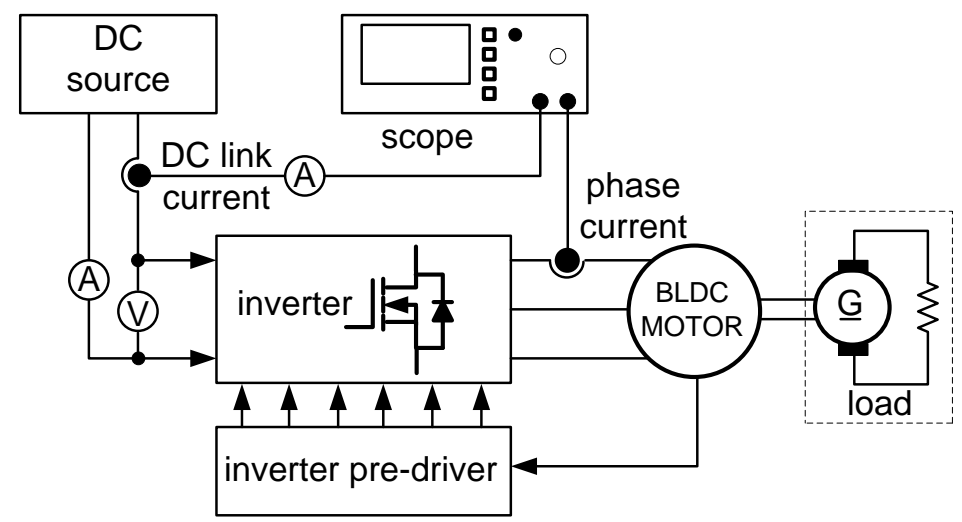

(a) 


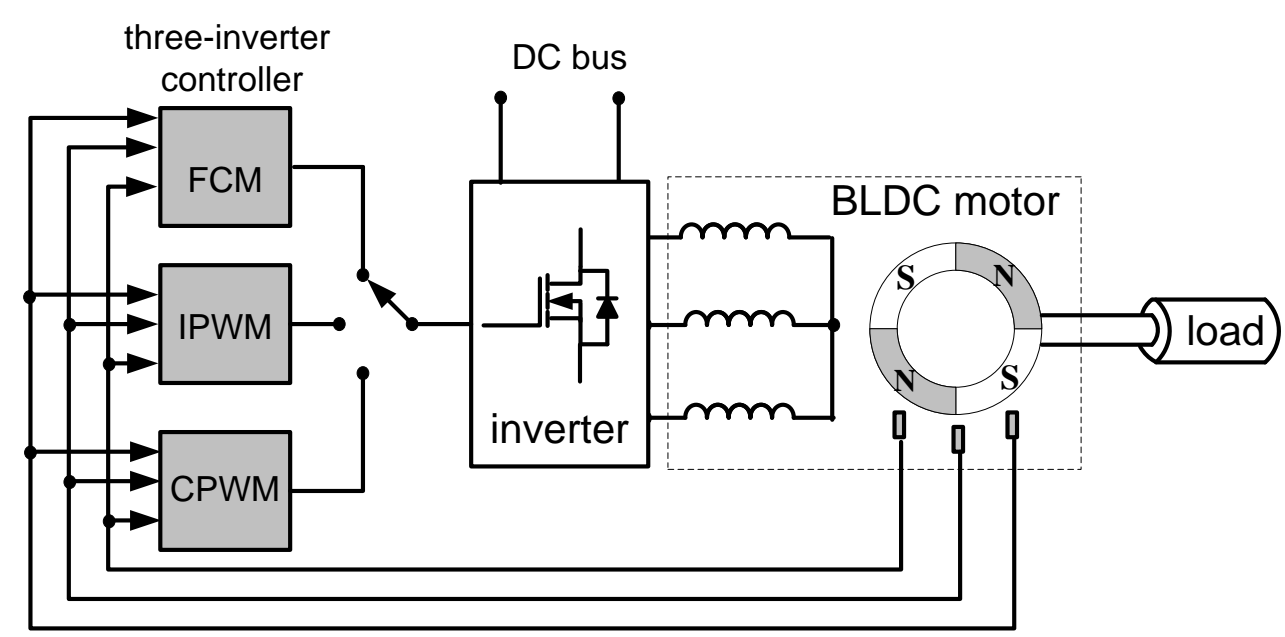

(b)

Figure 5. Experimental setup; (a) measuring system, (b) control system.

Three-phase, six poles BLDC motor with outer rotor is used as test motor which is mainly used in office machines in this study. BLDC motor is coupled a permanent magnet DC generator which is used BLDC motor load. BLDC motor has been run under various loads and injected three PWM methods and performance of BLDC motor has been examined. BLDC motor specifications are shown in Table 2

Table 2. Specifications of BLDC motor using in experiment.

\begin{tabular}{|c|c|c|c|c|c|c|c|c|c|}
\hline Brand & $\begin{array}{c}\text { Rated } \\
\text { voltage } \\
(\mathbf{V})\end{array}$ & $\begin{array}{c}\text { Rated } \\
\text { Torque } \\
(\mathbf{m N m})\end{array}$ & $\begin{array}{c}\text { Rated } \\
\text { speed } \\
(\mathbf{r p m})\end{array}$ & $\begin{array}{c}\text { Rated } \\
\text { vurrent } \\
(\mathbf{A})\end{array}$ & $\begin{array}{c}\text { Back } \\
\text { EMF } \\
\text { constant } \\
(\mathrm{V} / \mathbf{k r p m})\end{array}$ & $\begin{array}{c}\text { Number } \\
\text { of poles }\end{array}$ & $\begin{array}{c}\text { Phase } \\
\text { resistance } \\
(\Omega)\end{array}$ & $\begin{array}{c}\text { Phase } \\
\text { iductance } \\
(\mathbf{m H})\end{array}$ & $\begin{array}{l}\text { Rotor } \\
\text { type }\end{array}$ \\
\hline $\begin{array}{c}\text { Shinano } \\
\text { Kenshi }\end{array}$ & $\mathbf{2 4}$ & $\mathbf{1 6 0}$ & $\mathbf{1 8 0 0}$ & $\mathbf{2 . 1}$ & $\mathbf{2 . 5 4}$ & $\mathbf{6}$ & $\mathbf{0 . 7 1}$ & $\mathbf{0 . 9 3 7}$ & outer \\
\hline
\end{tabular}

Experiment is done by loading the same load to BLDC motor which is running three various speeds by employing three PWM switching methods.

\section{Experimental Results}

Experimental results consist of three sections. These are; testing gate signals, measuring DC link and motor phase currents and examination of results.

\subsection{Test of gate signals}

Initially, the gate signals of each inverter controller have been measured and tested. It has been found that the gate signals are the same as in theory as it shown in Fig. 6. 


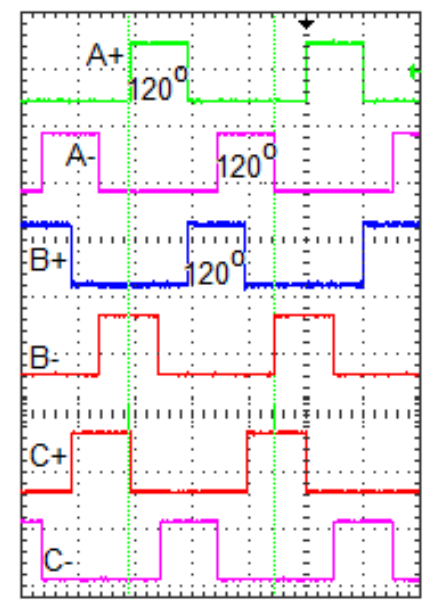

(a)

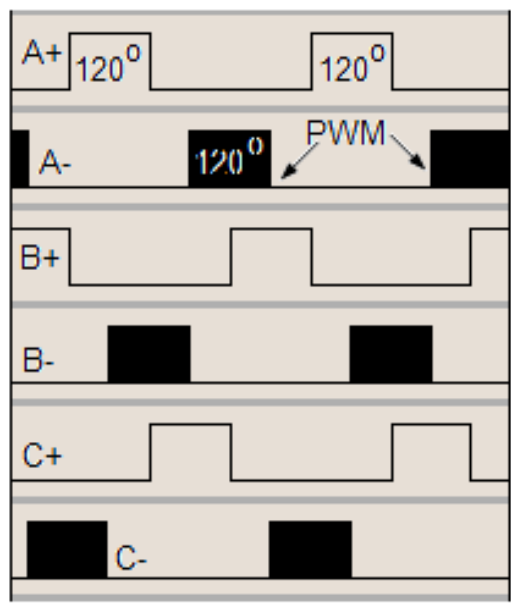

(b)

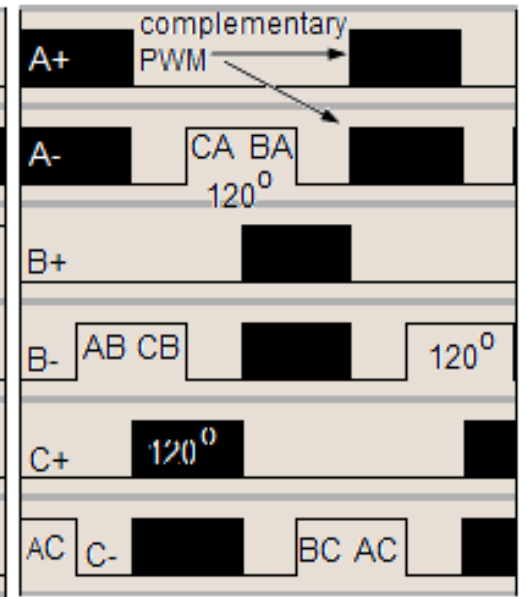

(c)

Figure 6. Inverter switching gate signals; (a) variable DC bus voltage, (b) independent PWM, (c) complementary PWM.

Fig. 6 illustrates that gate signals of three drivers are different from each others. It is understood from Fig. 6(a), each transistor in inverter remains conduction mode during 120-electrical degree. In this switching mode, PWM mode is not inserted to gates of switching elements. BLDC motor speed is varied by varying the inverter input DC bus voltage. Fig. 6(b) shows that the PWM signals are applied only to A-, B- and Ctransistors which are connected to the negative terminal of the DC source shown by black parts. $\mathrm{A}+, \mathrm{B}+$ and $\mathrm{C}+$ transistors are on full conduction mode during 120electrical degree. Thus, while the transistors are connected to positive terminal of DC source are on 120-degree conduction mode, but A-, B- and C- transistors are run PWM mode during 120-electrical degree. BLDC motor speed is varied by changing duty cycle of gate signals of A-, B- and Ctransistors. Fig. 6 (c) depicts that the transistors of the same phase $(\mathrm{A}+$ and $\mathrm{A}-$, $\mathrm{B}+$ and $\mathrm{B}-, \mathrm{C}+$ and $\mathrm{C}-$ ) run in the $\mathrm{PWM}$ mode as it is shown by black parts. BLDC motor speed is changed by varying duty cycle of both upper and lower transistors of the same phase in this PWM mode. From Fig. 6, it is understood that all gate signals are perfectly generated by pre-drivers.

\subsection{Measuring DC link and phase currents}

After the experimental setup has been build, three switching methods are tested and effects of these switching methods on the BLDC motor are examined. DC link and phase currents are measured and showed by oscilloscope as it shown in Figs. 9 and 10.

\subsection{Experimental results}

The BLDC motor has been run under constant load employing three PWM methods according to three speed ranges in order to reach more accurate results. Thus, the effects of these PWM methods on the inverter and BLDC motor have been compared. Table 3 shows that measured DC link and motor phase currents through the experiments.

If it is necessary to express as a percentage of DC link current for comparison, the following expression 5 can be used; 
$\Delta I_{d c}=\frac{I_{d c F C M}-I_{d c C P M}}{I_{d c F C M}} \cdot 100$

From Table 3 BLDC motor rotates at $1333 \mathrm{rpm}$ under the same load for each current control modes. The inverter drives $3.11 \mathrm{~A}$ in full conduction mode, $2.35 \mathrm{~A}$ in independent PWM mode and 2.30A in complementary PWM mode, from the DC source despite the load remains the same for each current control mode. Using expression (5) for comparison FCM with CPWM;

$\Delta I_{d c}=\frac{3.11-2.34}{3.11} \cdot 100=24 \%$
According this result, the driving system which is using CPWM mode draws $26 \%$ less current from DC source than full conduction mode. And the same way for comparison independent PWM with CPWM;

$\Delta I_{d c}=\frac{3.11-2.35}{3.11} \cdot 100=24 \%$ are obtained.

Similarly, the driving system which is using CPWM and IPWM modes draw 24\% less current from DC source than FCM current control mode. BLDC motor phase currents are almost equal to each other because the motor load is constant trough the all experiments.

Table 3. BLDC motor phase and DC link currents various speed ranges under the same load.

\begin{tabular}{|c|c|c|c|c|c|c|c|c|c|}
\hline Speed (rpm) & \multicolumn{3}{|c|}{600} & \multicolumn{3}{|c|}{1000} & \multicolumn{3}{|c|}{1333} \\
\hline $\begin{array}{l}\text { Switching } \\
\text { method }\end{array}$ & $\sum_{i}$ & $\sum_{2}$ & $\sum_{i=1}^{\sum}$ & 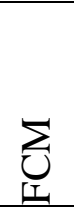 & $\sum_{i=1}^{\infty}$ & $\sum_{0}^{\infty}$ & 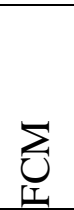 & $\sum_{i=1}^{\infty}$ & $\sum_{\substack{0 \\
0}}^{\infty}$ \\
\hline Phase current (A) & 1.36 & 1.36 & 1.36 & 2.11 & 2.15 & 2.13 & 2.73 & 2.74 & 2.73 \\
\hline DC link current (A) & 1.64 & 0.59 & 0.59 & 2.47 & 1.44 & 1.43 & 3.11 & 2.35 & 2.34 \\
\hline
\end{tabular}

It is seen from Fig. 7 the DC link currents when the BLDC motor rotates at 600,1000 and $1333 \mathrm{rpm}$, when the load is $2 \Omega$ which is connected to dc generator. It is clearly seen Fig. 7, DC link currents are very closely to each other for IPWM and CPWM methods, but DC link currents in FCM method are higher than other two methods. Whereas DC link voltage is lower in FCM than two other modes (Fig. (8)). 


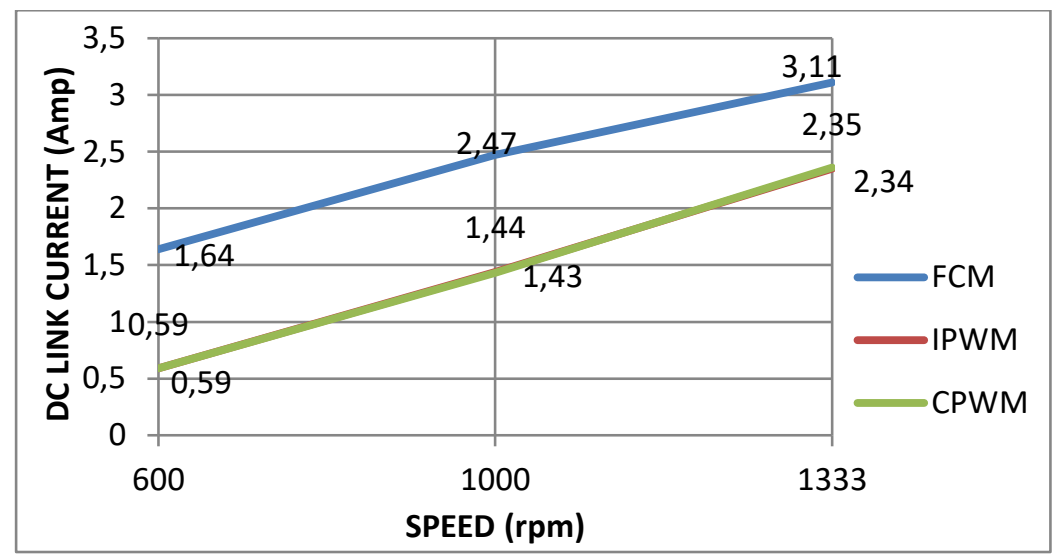

Figure 7. Inverter DC link currents when the DC generator load is $2 \Omega$.

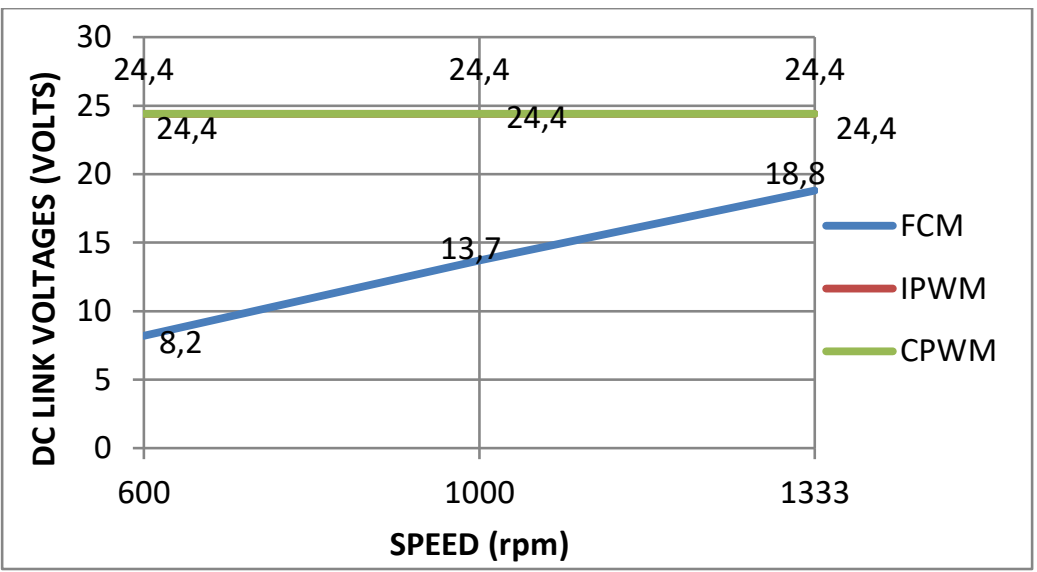

Figure 8. Inverter DC link Voltages when the DC generator load is $2.6 \Omega$.

As it is seen from Fig. (7), while DC link currents are higher in FCM than IPWM and CPWM methods, but DC link voltages are lower in FCM method than the IPWM and CPWM schemes. In this experimental study, the effect of three different PWM methods on the dynamic behavior of BLDC motor is also investigated. For this purpose, the BLDC motor has been operated at the same speed under the same load and the dynamic response of the motor has been examined.

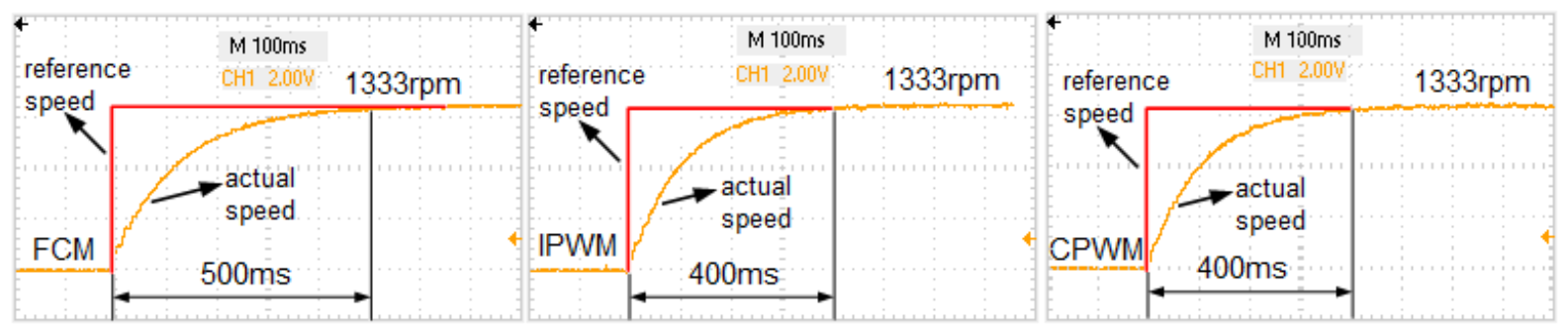

(a) (b) (c)

Figure 9. Speed up response of BLDC motor for three PWM current control methods for same speed under same load. 
It is clearly seen from Fig. 9, 1333 rpm reference speed has given to BLDC motor in all three PWM modes and the BLDC motor reaches final speed (1333 rpm) within $400 \mathrm{~ms}$ when it runs in CPWM and IPWM modes. Thus, when the BLDC motor operates in CPWM and IPWM modes, the speed response is faster than FCM. CPWM and IPWM modes allow the BLDC motor to speed response faster than FCM. FCM gives the BLDC motor the slow speed response, BLDC motor reaches to final speed $(1333 \mathrm{rpm}) 100 \mathrm{~ms}$ later in this scheme.

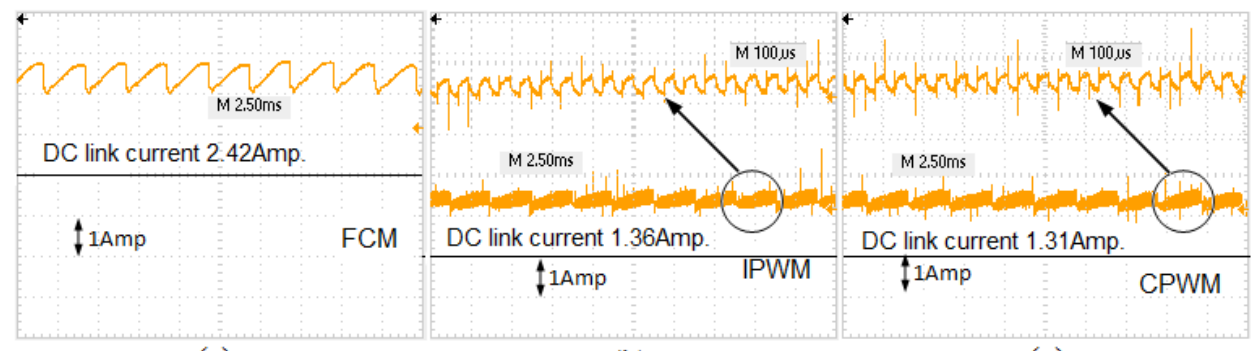

(a)

(b)

(c)

Figure 10. When BLDC motor working rated phase current (2.1 Amp.) DC link currents with respect to three PWM schemes.

Fig. 10 shows DC link currents, when BLDC motor has been run under a certain load drawing its rated phase current 2.1 Amperes from inverter. Inverter has drawn higher DC link current from DC source than the two other PWM modes when BLDC motor working in FCM. When inverter has worked on IPWM and CPWM modes, their DC link currents are very close each other as it is shown in Fig. 7, 10 (b, c) and Table 3.

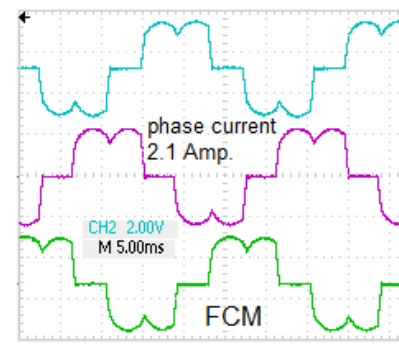

(a)

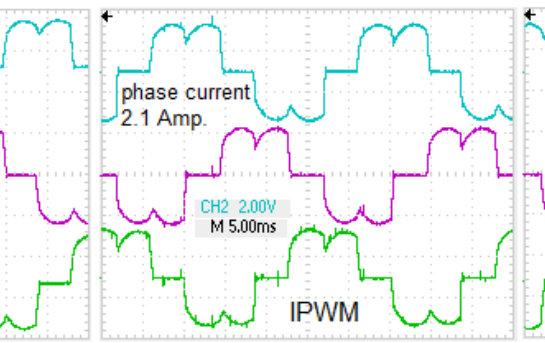

(b)

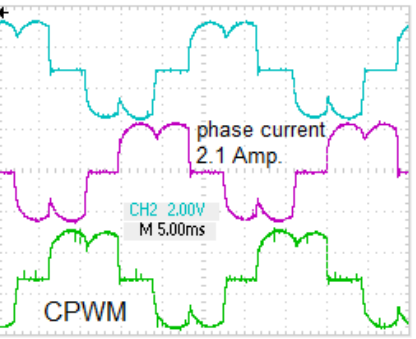

(c)

Figure 11. BLDC motor phase currents with respect to three PWM modes when the motor is working its rated phase current.

BLDC motor phase currents have been adjusted its rated current value and they have been recorded as they are seen in Fig. 11. Due to fact that BLDC motor speed is adjusted by varying DC link voltage in
FCM, DC link voltage has been decreased to 10.4 Volts from 24.5 Volts to make phase current is 2.1 Amps. On the other hand, DC link voltage is 24.5 Volts when BLDC motor works other two PWM modes, since 
motor speed controlling is achieved by changing duty cycle in IPWM and CPWM modes. When the BLDC motor works with FCM scheme, one transistor is in conduction mode for 8.4 milliseconds. While BLDC motor works both with IPWM and CPWM modes, one transistor is in conduction time for 20 microseconds so duty cycle is $40 \%$.

Table 4. Inverter and BLDC motor parameters various speed ranges under the same load.

\begin{tabular}{|c|c|c|c|c|}
\hline \multirow{2}{*}{$\begin{array}{l}\text { Switching } \\
\text { mode }\end{array}$} & \multirow[t]{2}{*}{ Parameters } & \multicolumn{3}{|c|}{ Frequency $(\mathrm{Hz})$ and motor speed (rpm) } \\
\hline & & $30(600)$ & $50(1000)$ & $66.66(1333)$ \\
\hline \multirow{6}{*}{ FCM } & Phase current $(\mathrm{A})$ & 1.75 & 2.63 & 3.26 \\
\hline & $\begin{array}{l}\text { DC link current } \\
\text { (A) }\end{array}$ & 2.08 & 2.97 & 3.66 \\
\hline & $\begin{array}{l}\text { DC link voltage } \\
\text { (V) }\end{array}$ & 8.2 & 13.7 & 18.8 \\
\hline & $\mathrm{T}_{\text {on }}(\mathrm{ms})$ & 11.4 & 6.8 & 5.2 \\
\hline & DC power $(\mathrm{W})$ & 17 & 40.6 & 68.8 \\
\hline & Phase voltage $(\mathrm{V})$ & $8.2 * 0.41=3.36$ & $13.7 * 0.41=5.61$ & $18.8 * 0.41=7.7$ \\
\hline \multirow{6}{*}{ IPWM } & Phase current $(\mathrm{A})$ & 1.74 & 2.6 & 3.26 \\
\hline & $\begin{array}{l}\text { DC link current } \\
\text { (A) }\end{array}$ & 0.71 & 1.66 & 2.81 \\
\hline & $\begin{array}{l}\text { DC link voltage } \\
\text { (V) }\end{array}$ & 24.4 & 24.4 & 24.4 \\
\hline & $\mathrm{T}_{\mathrm{on}}(\mu \mathrm{s})$ & 16 & 27 & 37 \\
\hline & DC power $(\mathrm{W})$ & 17 & 40.5 & 68.5 \\
\hline & Phase voltage $(\mathrm{V})$ & $24.4 * 0.32 * 0.41=3.20$ & $24.4 * 0.54 * 0.41=5.4$ & $24.4 * 0.74 * 0.41=7.4$ \\
\hline \multirow{6}{*}{ CPWM } & Phase current $(\mathrm{A})$ & 1.75 & 2.60 & 3.24 \\
\hline & $\begin{array}{l}\text { DC link current } \\
\text { (A) }\end{array}$ & 0.70 & 1.67 & 2.79 \\
\hline & $\begin{array}{l}\text { DC link voltage } \\
\text { (V) }\end{array}$ & 24.4 & 24.4 & 24.5 \\
\hline & $\mathrm{T}_{\text {on }}(\mu \mathrm{s})$ & 16 & 27 & 37 \\
\hline & DC power $(\mathrm{W})$ & 17 & 40.6 & 68.35 \\
\hline & Phase voltage $(\mathrm{V})$ & $24.4 * 0.32 * 0.41=3.20$ & $24.4 * 0.54 * 0.41=5.4$ & $24.4 * 0.74 * 0.41=7.4$ \\
\hline
\end{tabular}

As it is seen in Table 4, when BLDC motor rotates at 600, 1000 and $1333 \mathrm{rpm}$, inverter draws from DC power supply 17, 40.6 and 68 Watts power respectively. Duty cycles are equal in CPWM and IPWM modes (16, 27, $37 \mu \mathrm{s}$ ) but in FCM, due to it is full conduction mode, duty cycles are 11.4, 6.8 and $5.2 \mathrm{~ms}$. Phase voltages are equal each others for three PWM schemes so BLDC motor performance is the same for CPWM and IPWM modes. 


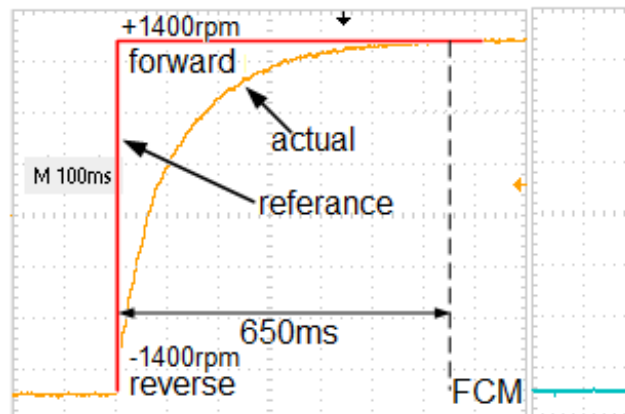

(a)

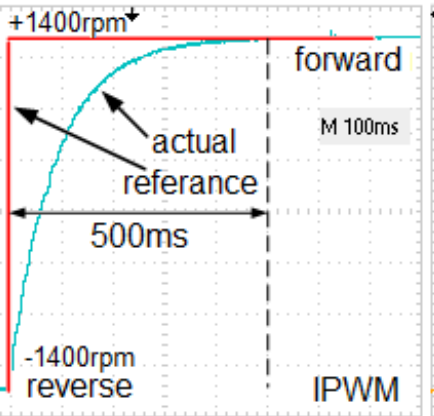

(b)

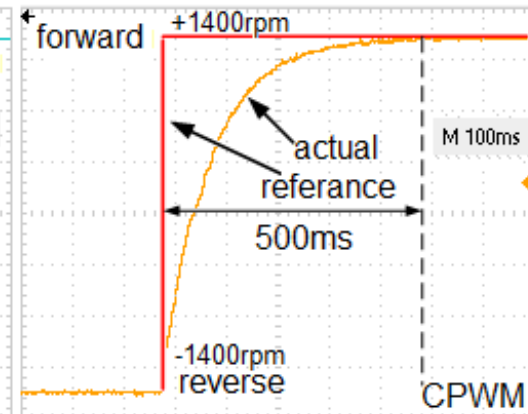

(c)

Figure 12. Reversible speed performance of BLDC motor according to three PWM schemes.

Reversible performance of BLDC motor is also tested by using FCM, IPWM and CPWM schemes. In Fig. 12, the direction of rotation of the BLDC motor suddenly changed when the BLDC motor rotating in the reverse direction at $1400 \mathrm{rpm}$ so 2800 rpm speed reference has given to BLDC motor under the same load. In Fig. 12 (b) and (c), BLDC motor reaches to new speed reference within 500 milliseconds from reverse direction $(-1400 \mathrm{rpm})$ to forward direction (+1400 rpm). But Fig. 12(a) shows that BLDC motor reaches to new speed reference within 650 milliseconds. Thus, Fig. 12 shows BLDC motor performance is slower than two other PWM modes in FCM scheme and it is found IPWM and CPWM schemes gives to BLDC motor the same performance.

\section{Consultations}

Three types of inverter controllers are designed on provided that the inverter part remains the same; these controllers are 1full conduction mode controller, 2independent PWM controller and the last one 3- complementary PWM mode controllers. These three current control methods have different effects on the inverter, DC source and BLDC motor. These effects can be summarized as follows;

\subsection{Full conduction mode (FCM):}

Owing to draw the higher current from the DC source than two other PWM modes, this method is not suitable battery powered motor driving applications. Although designing and application of this method is easy, this current control method has unwanted noise for high power BLDC motors. Furthermore this conduction mode gives the BLDC motor the slowest speed response. Since this configuration gives slow response to BLDC motor, it is not suitable the applications where require fast dynamic response such as robotic and servo applications. This current control method can be preferred to the BLDC motors which have very low phase winding inductance. When PWM method applies to very low phase winding inductance, phase current becomes the same shape with the PWM voltage and phase current is not continuous. Full conduction scheme can be used where the DC source voltage is lower than the BLDC motor rated voltage and in small power applications. Start stop operation of BLDC motor should not be done using DC link switch, otherwise BLDC motor performance will be very slow. Start/stop operation should be done in position decoder part as it shown in Fig. 2. 


\subsection{Independent PWM mode (IPWM):}

The current drawing from DC source is relatively low according to FCM in this current control mode and it draws DC link current very close to CPWM method. Implementing of this configure is simple and cheaper. Although this PWM scheme structure is simple and more economical, it gives the experimental BLDC motor the same performance as the CPWM method as it is seen Figs. 9 (b, c), 12 (b, c) and Table 4. This PWM scheme results slower response in BLDC motors which has highly inductance phase winding.

\subsection{Complementary PWM mode (CPWM):}

Implementation of this current control mode is more complex than two others modes. Owing to draw the lower current from DC source according to FCM method, this current control method must prefer mainly battery powered applications such as portable devices, battery powered vehicles, solar power applications. In addition to these, this current control method provides the BLDC motor fast dynamic speed response which is required in servo applications. In this respect, CPWM method should especially prefer on applications that require fast dynamic response such as robotics, medical areas, packaging, office machines and industrial applications.

\section{References}

Arjun V. N, Akhilesh H. N, Balakrishnan G, Vishnu T. S, Sojian V. 2016. "Speed Control of a BLDC Motor Using PWM Control Technique", International journal of innovative research in electrical, electronics, instrumentation and control engineering (IJIREEICE), 4(6), 18-21.

Batham R, Singh R. 2017. "Speed Control of Brushless DC Motor Using Different Intelligence Schemes", International Research Journal of Engineering and Technology (IRJET), 4(10), 654-659.

Gamazo-Real J. C, Vázquez-Sánchez E, Gómez-Gil J. 2010. "Position and Speed Control of Brushless DC Motors Using Sensorless Techniques and Application Trends", Sensors, 10 (7), 6901-6947. https://www.efxkits.us"difference-

between-insulated-gate-bipolar-transistorigbt-and-mosfet" date of access: 03.03.2019.

Lengade S.R, Mahjan D. 2018. "Speed Control of BLDC Motor by using PWM Technique", International Journal of Innovative Research in Science, Engineering and Technology, 7(1), 109115 .

Mahesh S, Dighe A, Surse S. 2017. "Speed control of brushless dc (bldc) motor using pulse width modulation (pwm) technique", International Journal of Modern Trends in Engineering and Research (IJMTER), 4(4), 167-170.

Ohm D. Y, Oleksuk R. J. 2002. "Influence of PWM Schemes and Commutation Methods for DC and Brushless Motors and Drives", Drivetech, Inc. Northrop Grumman Poly-Scientific. 1-9.

Ohm D.Y, Park J. H. 1999. "About commutation and current control methods for brushless motors", 28th Annual Symposium Incremental Motion Control Systems and Devices. San Jose, CA, 1-6.

Ozgenel M. C. 2017. "Design, Implementation, and Application of 150Degree Commutation VSI to Improve Speed Range of Sensored BLDC Motor", Review of Scientific Instruments. 88(9), 18. 
Patel Vinod KR Singh and Pandey A. K. 2013. "Modeling and Performance Analysis of PID Controlled BLDC motor and Different Schemes of PWM Controlled BLDC Motor", International Journal of Scientific and Research Publications, 3(4), $1-14$.

Pindoriya R. M, Rajendran S, Chauhan P. J. 2014. "Speed Control of BLDC Motor using Sinusoidal PWM Technique", International Journal of Advance Engineering and Research Development (IJAERD) ETCEE Rajkot IN, 1-6.
Sathyan A, Milivojevic N, Lee Young-Joo, Krishnamurthy M, Emadi A. 2009. "An FPGA-Based Novel Digital PWM Control Scheme for BLDC Motor Drives", IEEE Transactions on Industrial Electronics, 56(8), 3040-3049.

Tade S.L, Sor R, Kinkar S.V. 2016. "Digital PWM Techniques and Commutation for Brushless DC Motor Control Applications: Review", International Journal of Advanced Research in Electrical, Electronics and Instrumentation Engineering, 5(4), 2519-2524. 